\title{
EARLIER SPRING ARRIVAL OF THE MOUNTAIN BLUEBIRD IN CENTRAL ALBERTA, CANADA
}

MYRNA PEARMAN and LEO DE GROOT, Ellis Bird Farm, Box 5090, Lacombe, Alberta, T4L 1W7, Canada; mpearman@ellisbirdfarm.ca

GEOFFREY L. HOLROYD and STEPHANIE THUNBERG, Beaverhill Bird

Observatory, Box 1418, Edmonton, Alberta, T5J 2N5, Canada

ABSTRACT: Much attention has been given to the topic of bird phenology in response to climate change. While strong evidence supports a general pattern of advancement in spring migrants' arrival dates with warming temperatures, the mechanisms underlying these changes are not clearly understood. We summarize the spring arrival of the Mountain Bluebird (Sialia currucoides) in central Alberta from 58 years of data and examine the influence of temperature and snow cover on the patterns of arrival. We hypothesized that a significant advance in the Mountain Bluebird's first arrival date was related to weather variables. In central Alberta, March temperatures increased, and first arrival dates for the Mountain Bluebird advanced 0.33 days per year from 1961 to 2018 or 19 days over the 58 years. However, temperatures on the date of arrival have cooled slightly $\left(2.8^{\circ} \mathrm{C}\right)$ over the study period, and snow depth on the date of arrival decreased slightly $(1.5 \mathrm{~cm})$ over the study period, which may influence early migrants' opportunities for foraging. Although Mountain Bluebirds have arrived at our central Alberta study area considerably earlier over the past decades, temperatures and snow depth have been highly variable, suggesting that the species is likely responding to multiple cues that influence its arrival dates. Given the Mountain Bluebird's migratory nature, environmental and behavioral stimuli en route to breeding areas likely exert considerable influence on arrival dates.

Studies of the phenology of spring migration in birds breeding in the North Temperate Zone have sought to determine which species are adjusting their arrival times in response to changing temperatures and other variables associated with climate change (Swanson and Palmer 2009, Ward et al. 2016). The date of spring departure from the winter range, migration time, and date of arrival at the breeding grounds can all be affected by local weather conditions from the start to end of migration (Pulido 2007, Lehikoinen and Sparks 2010). While changing day length (Rowan 1932) and endogenous hormonal changes (Gwinner 1986) are the initial triggers for migration (Gienapp et al. 2007, Pearce-Higgins and Green 2014), variables such as temperature, wind, and other weather conditions modify the time and length of migration (Winkler et al. 2016). In response to climate change, a general pattern of advancement of spring movements and breeding of migratory birds has been found, irrespective of the metric considered (Winkler et al. 2016). Phenological responses to climate change may also be dependent on the distance of migration, with long-distance migrants' phenological response being smaller than that of short-distance migrants (Knudsen et al. 2011). However, variability among species is wide and poorly understood, and the mechanisms underlying these changes need further study (Knudsen et al. 2011). Furthermore, seasonally asynchronous climate change-when a region warms during some parts of the year then cools in others-may constrain species' responses to climate change (Senner et al. 2018).

The Mountain Bluebird (Sialia currucoides) is a common harbinger of 
spring in many parts of northern North America. It breeds from Alaska across western Canada to the western contiguous USA, and winters from the western USA to central Mexico (Johnson and Dawson 2019). By means of light-level geolocators, Mountain Bluebirds that nest in central Alberta have been tracked as wintering in the southwestern USA and northern Mexico (K. C. Fraser unpubl. data). Accordingly, bluebirds nesting in this area are considered short-distance migrants and typically arrive in March. At least during the breeding season, terrestrial invertebrates, hawked from perches, are the species' primary food source (Herlugson 1982), so the birds require accessible and active insects and spiders upon their arrival. They also hoverhunt, especially on warm windy days (Power and Lombardo 1996). Therefore, they rely on relatively benign conditions that facilitate the emergence and activity of their insect prey. The Mountain Bluebird is more insectivorous than most North American thrushes but during the fall and winter does eat berries (Johnson and Dawson 2019). Although it is not known if berries are consumed during spring migration, when the birds first arrive on their breeding grounds, and/or during periods of inclement weather when insect prey are temporarily unavailable, their spring and summer diets may be supplemented to some extent by berries. Nevertheless, Beal (1907) found that in California Mountain Bluebirds ate few berries.

Mountain Bluebirds nest in tree cavities or, as in this study area, in artificial nest boxes. Since bluebirds do not make their own nest cavities and are dependent on cavities made by woodpeckers, they are considered secondary cavity nesters. Therefore, competition for limited nest sites results in pressure for males to arrive at breeding grounds and claim sites before competitors (Winkler et al. 2016).

A common metric for detecting changes in migration timing is first arrival date (Goodenough et al. 2015). This method may have shortcomings since it may reflect an effect on the earliest-arriving birds that does not necessarily represent a shift in the arrival dates of the total population, and detections are dependent on observer effort and chance (Knudsen et al. 2011, Lehikoinen et al. 2019). Despite these potential shortcomings, first arrival date is easily measured and has broad appeal in long-term monitoring and citizen-science programs. We determined the changes in first arrival date from a 58-year record of the Mountain Bluebird in central Alberta (1961-2018). We investigated whether bluebirds were arriving earlier in the spring and, if so, what conditions they faced upon arrival. We assessed the effect of temperature and snow depth on first arrival date. Our hypothesis was that Mountain Bluebirds have been arriving earlier in central Alberta because of warmer March temperatures and shallower snow depths. In addition, we hypothesized that because of climate change, birds should face, on average, similar conditions upon arrival across the study period despite the advancement in arrival date. We tested this hypothesis by comparing temperatures and snow depth to the dates when the birds first arrived.

\section{METHODS}

This study took place near Lacombe, in central Alberta, Canada (52 $28^{\prime}$ $06^{\prime \prime} \mathrm{N}, 113^{\circ} 44^{\prime} 13^{\prime \prime} \mathrm{W}$, elevation $916 \mathrm{~m}$ above sea level). Between 1961 and 
1981 (except in 1966, when no date was noted), Charlie and Winnie Ellis recorded first arrival dates on their 388-ha farm, where they monitored up to 250 nest boxes at a time when there were few other boxes in the surrounding area. In March, they drove local roadways, focusing their efforts on areas along Highway 597 where steep south-facing slopes were usually the first to be clear of snow and hence where the bluebirds were first seen (Winnie Ellis pers. comm., 1986). Their actions represent an early, valuable example of citizen science.

With the establishment of Ellis Bird Farm Ltd. in 1982, the Ellis's farmbased trail of nest boxes was expanded to cover $256 \mathrm{~km}^{2}$ around the farm. The responsibility for monitoring this trail, recording data, and banding Mountain Bluebirds was assumed by the farm's resident biologist. First arrival dates were recorded by Bryan Shantz from 1982 to 1986 and by Myrna Pearman from 1987 to 2018.

Starting in the 1980s, other bluebird trails were established throughout Alberta, and the trails' monitors looked for first spring arrivals in their respective areas. Hence some of the dates noted between 1983 and 2018 were reported by others from over a wider area, up to approximately $120 \mathrm{~km}$ in all directions. Nevertheless, all were within the Aspen Parkland Ecoregion (Bird and Bird 1967). Both Pearman and Shantz also drove local roads in mid-March and compiled reports of first arrival dates from other bluebird-trail operators in the wider area. When we received dates from several observers within the same year, we used the one closest to Ellis Bird Farm.

We obtained historical temperature and snow-depth data from Environment Canada (http://climate.weather.gc.ca/historical_data/search_historic_data_e.html). The records from the Red Deer Regional Airport, located $30 \mathrm{~km}$ southwest of Ellis Bird Farm, were the region's most extensive, and so we used these records in our analysis. Because at any given time weather conditions across the Aspen Parkland region of central Alberta are similar (Beaubien 2013), we had confidence that the data from this weather station reflected conditions across our study area.

March is the month when temperature increases in central Alberta are the greatest of any month (Beaubien 2013). We compared first arrival dates to spring temperatures and snow depths on 1, 15, and 31 March and found the results were similar to those for the whole month. Therefore, we used the mean temperature for the month as a predictor variable. We tested our prediction of an advancement in first arrival dates from 1961 to 2018 by a simple linear regression that included the first arrival date as the dependent variable and the year as a continuous explanatory variable. We rescaled the years to range from 1 to 58 by subtracting 1960 from each value. Likewise, we tested for trends in temperature and snow depth for the same years. We also tested for any correlation between first arrival date and temperature on the arrival dates, and likewise for snow depth on first arrival. Finally, we evaluated the most likely weather factors influencing the Mountain Bluebird's first arrival date with multiple linear regression models developed in the statistical package $\mathrm{R}$ ( $\mathrm{R}$ Core Team 2019). The model assessed how temperature on the first arrival date $\left({ }^{\circ} \mathrm{C}\right)$, snow depth on the first arrival date $(\mathrm{cm})$, mean March temperature, and mean March snowfall influenced the first arrival date from 1962 to 2018. Data from 1963, 1966, 2008, and 2017 were incomplete and not included in this analysis. We 
created a set of additive models that included all unique possible combinations of the four variables. We ranked the models by Akaike's information criterion corrected for sample size $\left(\mathrm{AIC}_{c}\right)$ and, following the approach of Burnham and Anderson (2002), used Akaike weights $\left(w_{i}\right)$ to assess the models' support. We averaged the estimated parameters across all models with the R package AICcmodavg (Mazerolle 2019) and considered parameters with 95\% confidence intervals that did not overlap zero to be biologically meaningful.

\section{RESULTS}

Over the past 58 years, the date of spring arrival of the Mountain Bluebird in central Alberta has advanced by 19 days (Figure 1). In the early 1960s, birds tended to arrive around $30 \mathrm{March}$, but by the 2010s, they were arriving around 11 March (Figure 1). The trend to earlier arrival over the study period $\left(r^{2}=0.37, P<0.001\right)$ yielded advancement of first arrival date at a rate of 0.33 days per year. The trend from 1961 to 1986, when only the Ellis siblings made observations around their farm, differed from that in the years after 1987, when more observers were involved over a larger study area (Figure 1). The trend toward earlier arrival was 0.66 days per year from 1961 to $1986\left(r^{2}=\right.$ $0.23, P=0.01)$ but 0.14 days per year from 1987 onward $\left(r^{2}=0.07, P=0.16\right)$.

While March temperatures varied substantially from year to year, the trend over the past 58 years in our study area has been an increase (Figure 2). Overall, the mean monthly average temperature for March trended upward, rising from $-5.2^{\circ} \mathrm{C}$ to $-3.2^{\circ} \mathrm{C}$, but this relationship was not statistically significant $\left(r^{2}=0.05, P=0.10\right)$. Bluebirds arrived significantly earlier when mean March temperatures were warmer (Figure $3 ; r^{2}=0.35, P=0.001$ ).

The variability of average snow depth for March was greater than that of temperature (Figure 4). For example, mean snow depth in March reached a maximum of $47.7 \mathrm{~cm}$ in 1974 and a minimum of $0.2 \mathrm{~cm}$ in 1968 . Snow depth in March increased from the late 1960s to the early 1970s, then decreased until the 2010s, when it began to increase again. Overall, however, mean March snow depth decreased from $17 \mathrm{~cm}$ to $11.5 \mathrm{~cm}$ over the study period, but this trend was not statistically significant (Figure $4 ; r^{2}=0.02, P=0.32$ ). Mountain Bluebirds arrived earlier in Marches when the average snow depth was low (Figure 5), a relationship that bordered statistical significance $\left(r^{2}=0.07\right.$, $P=0.06)$. The amount of snow present when Mountain Bluebirds arrived decreased from $12.7 \mathrm{~cm}$ in 1961 to $9.9 \mathrm{~cm}$ in 2018.

In our model-ranking exercise, two models carried nearly all the weight $\left(w_{i}=0.96\right.$; Table 1$)$. Only two of the four predictor variables (temperature on first arrival date and mean March temperature) had 95\% confidence intervals that did not overlap zero. The parameter estimate $( \pm 95 \%$ confidence interval) for temperature on first arrival date was 0.853 (confidence interval 0.295-1.412), and for mean March temperature was -1.835 (-2.534 to -1.137$)$. Over the 58 years of our study, the mean temperature on the first arrival date was $0.73^{\circ} \mathrm{C} \pm 3.70 \mathrm{SD}$, and the average mean March temperature was $-4.5^{\circ} \mathrm{C} \pm 3.82 \mathrm{SD}$. In relation to our parameter estimates for temperature, this indicates that Mountain Bluebirds generally arrived in central Alberta as temperatures broke the freezing point, and that bluebirds arrived earlier in warmer Marches. The parameter estimates for variables based on snow cover 


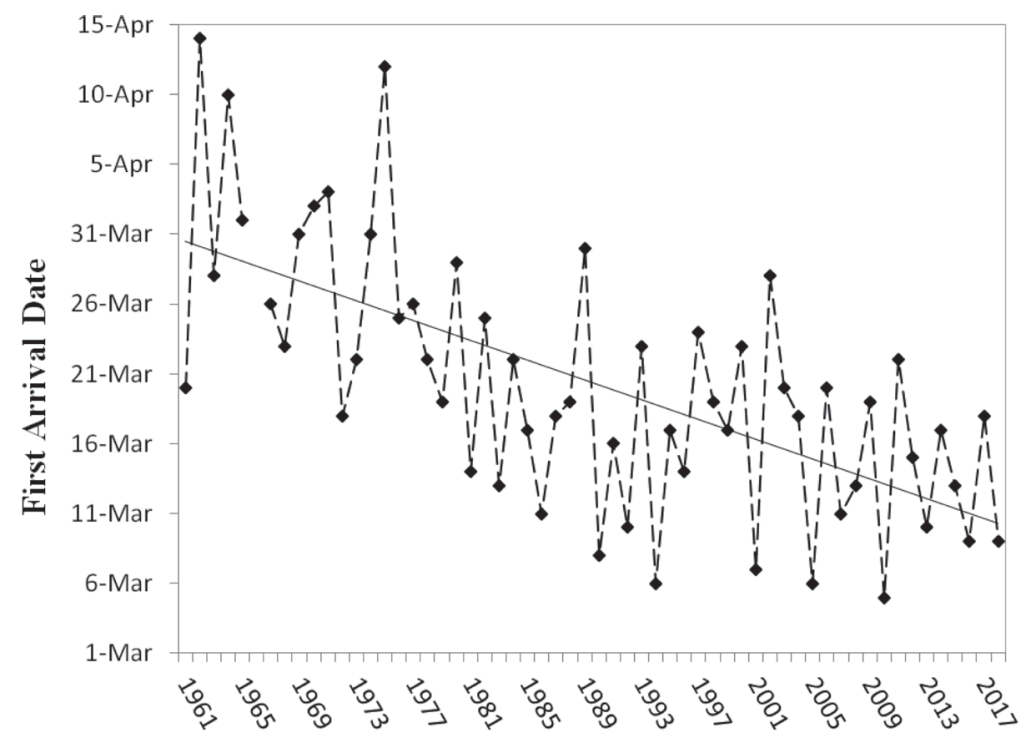

FIGURE 1. Dates of first arrival of the Mountain Bluebird in central Alberta, 1961-2018. Solid line represents linear regression $\left(r^{2}=0.371, P<0.001\right)$. No information was recorded in 1966.

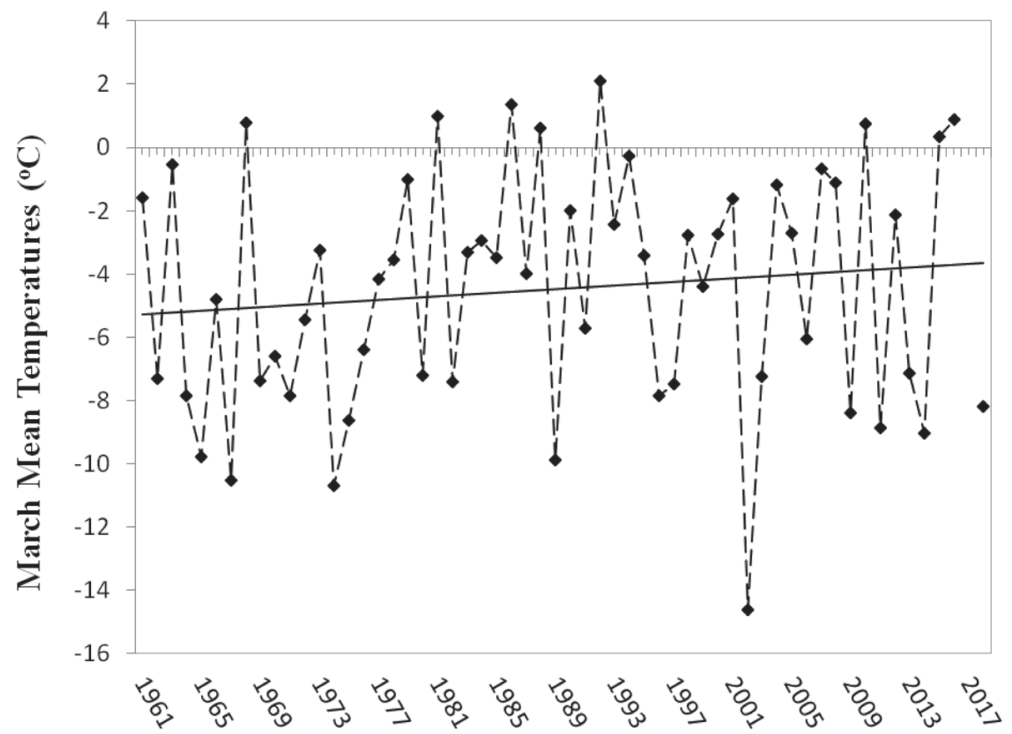

FIgure 2. Mean March temperature $\left({ }^{\circ} \mathrm{C}\right)$ recorded at Red Deer Regional Airport, Alberta, 1961-2018. Data for 2017 were unavailable. 


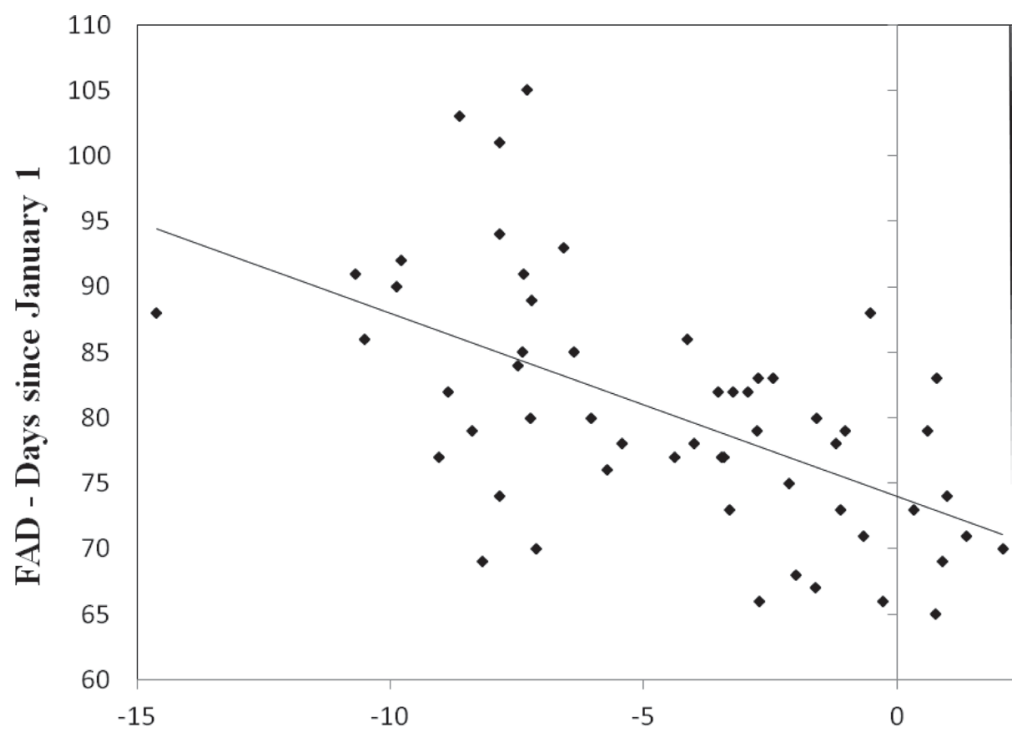

March Mean Temperature $\left({ }^{\circ} \mathrm{C}\right)$

FIgURE 3. Date of first arrival of the Mountain Bluebird in central Alberta as a function of mean March temperature $\left({ }^{\circ} \mathrm{C}\right)$ recorded at Red Deer Regional Airport, Alberta, 1961-2018. Data for 2017 were unavailable.

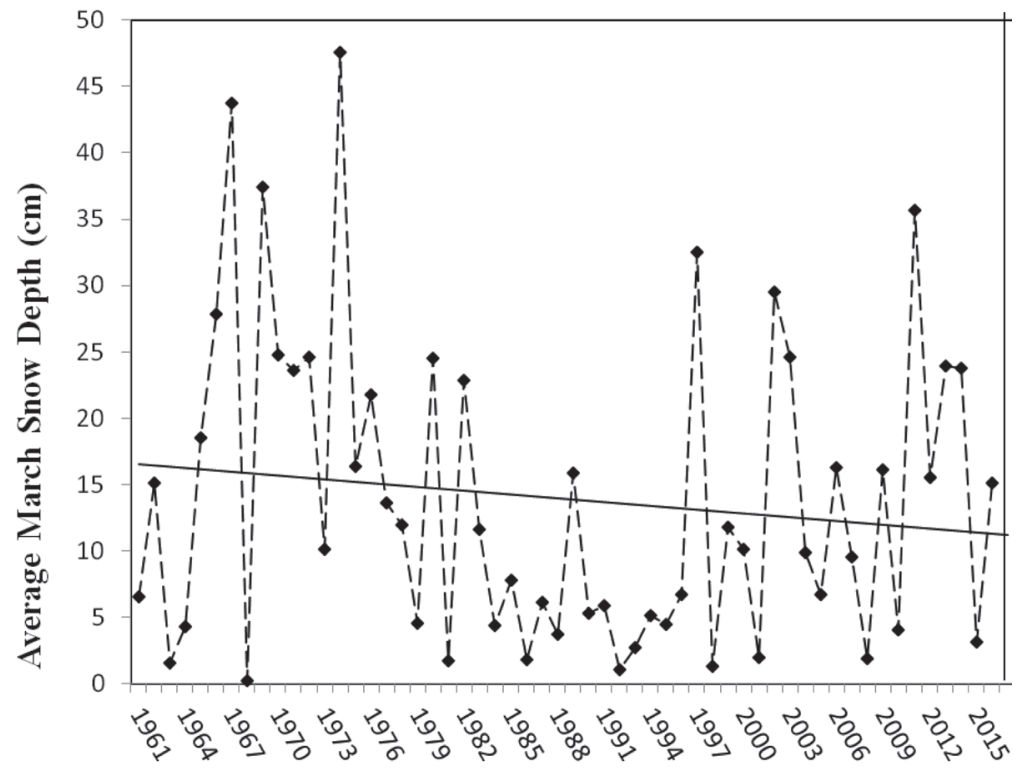

Figure 4. Average March snow depth $(\mathrm{cm})$ recorded at Red Deer Regional Airport, Alberta, 1961-2018. Data for 1961, 1963, 1966, 2008, and 2018 were unavailable. 


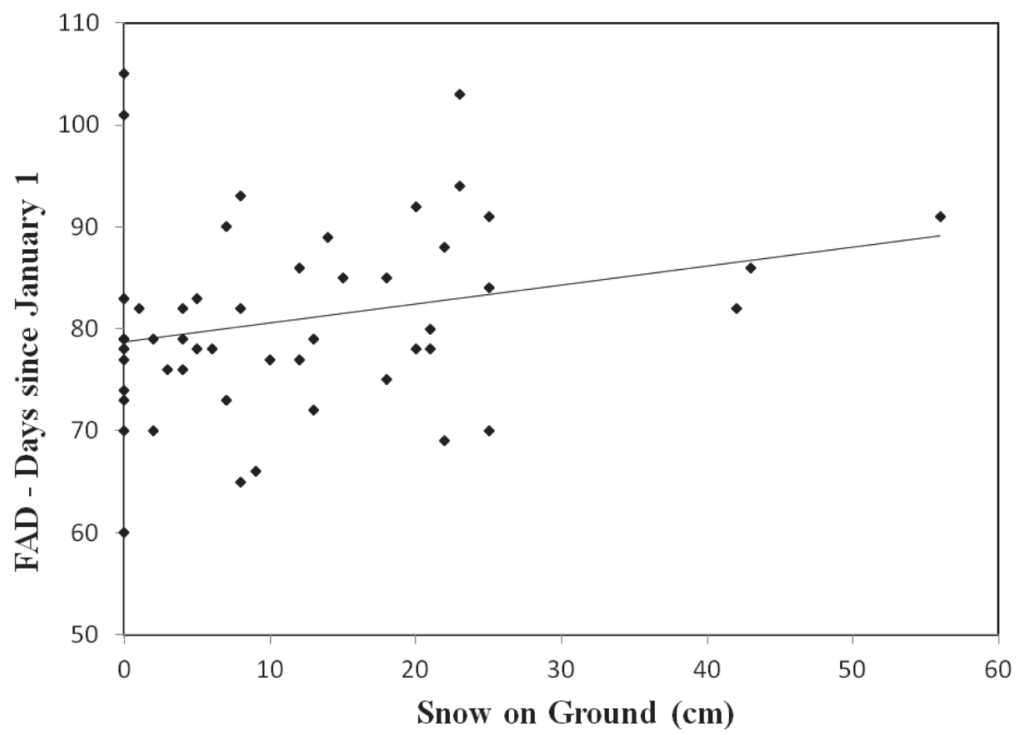

FIgURE 5. Date of first arrival of the Mountain Bluebird in central Alberta as a function of snow depth (cm) recorded at Red Deer Regional Airport, Alberta, 1961-2018. Data for 1961, 1963, 1966, 2008, and 2018 were unavailable.

largely overlapped zero: $95 \%$ confidence interval $-0.403-0.194$ for snow depth on first arrival date, $-0.197-0.678$ for mean March snow depth), suggesting that they were uninformative predictors of Mountain Bluebird arrival. Over the course of our study, the average snow depth on the first arrival date was $11.4 \mathrm{~cm} \pm 12.5 \mathrm{SD}$, and mean March snow depth was $13.9 \mathrm{~cm} \pm 11.5 \mathrm{SD}$.

TABLE 1 Rankings of Models Describing Effect of Environmental Variables on Dates of First Arrival of the Mountain Bluebirds in Central Alberta, 1961-2018

\begin{tabular}{lccc}
\hline Model $^{a}$ & $K^{b}$ & $\Delta \mathrm{AIC}_{c}{ }^{c}$ & $w_{i}{ }^{d}$ \\
\hline$T_{\mathrm{FAD}}+S_{\mathrm{FAD}}+T_{\mathrm{MAR}}$ & 5 & 0.00 & 0.63 \\
$T_{\mathrm{FAD}}+S_{\mathrm{FAD}}+T_{\mathrm{MAR}}+S_{\mathrm{MAR}}$ & 6 & 1.29 & 0.33 \\
$S_{\mathrm{FAD}}+T_{\mathrm{MAR}}$ & 4 & 6.50 & 0.02 \\
$S_{\mathrm{FAD}}+T_{\mathrm{MAR}}+S_{\mathrm{MAR}}$ & 5 & 7.70 & 0.01 \\
$T_{\mathrm{FAD}}+S_{\mathrm{MAR}}$ & 4 & 11.29 & 0.00 \\
Intercept & 2 & 43.88 & 0.00 \\
\hline
\end{tabular}

${ }^{a}$ The variables constituting the models are temperature $\left({ }^{\circ} \mathrm{C}\right)$ on first arrival date $\left(T_{\mathrm{FAD}}\right)$, snow depth $(\mathrm{cm})$ on first arrival date $\left(S_{\mathrm{FAD}}\right)$, mean March temperature $\left({ }^{\circ} \mathrm{C} ; T_{\text {MAR }}\right)$, and mean March snow depth ( $\left.\mathrm{cm} ; S_{\mathrm{MAR}}\right)$. Only the top five models and the intercept-only model are shown.

${ }^{b}$ Number of parameters.

'Difference between model's Akaike's information criterion corrected for sample size $\left(\mathrm{AIC}_{c}\right)$ and the lowest $\mathrm{AIC}_{c}$ value (352.3).

${ }^{d}$ Relative weight of $\mathrm{AIC}_{c}$ attributed to model. 


\section{DISCUSSION}

This study confirmed our hypothesis and supports earlier findings (Lane and Pearman 2003) that spring arrival of Mountain Bluebirds breeding in central Alberta has advanced. Lane and Pearman (2003) found the arrival date had advanced by 16 days over 40 years since 1961 ( 0.4 days per year). Over a span of 58 years, first arrival dates have advanced by 19 days, a statistically significant finding. The rate of change found in our study ( 0.33 days per year) is more than double the rate of change in bird-arrival dates found at Buffalo, New York, by DeLeon et al. (2011) over a similar period. They reported that from 1967 to 2008, short-distance migrants arrived earlier by an average 0.15 days per year, which is the same as the rate of change in the latter part (after 1987) of our study. As in our study, DeLeon et al. (2011) found warming spring temperatures correlated with earlier arrival dates. The advance of 0.15 days per year is the same as the rate of average annual advance of the last day of frost across North America (Schwartz et al. 2006). The more rapid rate of change in first arrival date ( 0.33 days per year) for the Mountain Bluebird in central Alberta is similar to the 0.31 days per year change of first arrival date for birds in Europe (Thackeray et al. 2010). A review of migration timing of 195 species at 21 bird observatories in Europe and North America, based on 57 years of daily data, found that birds' spring arrival had advanced by one week over 50 years, or 0.14 days per year (Lehikoinen et al. 2019). They compared the timing of migration as a whole, not just first arrival dates, yet found values similar to those above.

We presume this advance in first arrival dates is an effect of global climate change. Mean temperatures in our study area in March increased by $2.7^{\circ} \mathrm{C}$ from 1961 to 2018, but because the bluebirds arrived earlier, the temperatures on the date of their arrival cooled by nearly $3.0^{\circ} \mathrm{C}$ over the same period. However, snow depth at first arrival date decreased (by $3.6 \mathrm{~cm}$ ) over the long term, a factor that may favor foraging by exposing more bare ground, especially on south-facing slopes. Our analysis suggested that the mean March temperature and temperature on the first arrival date were the most significant weather factors that affected that date. Mountain Bluebirds rely on early spring temperatures warm enough for terrestrial invertebrates, their primary food source, to be active and accessible on bare ground. Thus our study suggests that the bluebirds were responding to warming March temperatures.

Advancement of first arrival date was more pronounced prior to the late 1980s than after 1990 (Figure 1). Lehikoinen et al. (2019: figure 3) found a similar tendency to less change in arrival dates after the late 1990s. The similarity in their rate of change and that noted in our study may indicate that certain species are approaching a limitation of the ability of their arrival dates to advance further (Senner et al. 2018). In early spring migrants such advancement may be constrained by cold, wet spring weather (Holroyd and Beaubien 1997a, b).

The urgency for birds, including cavity-nesting birds, to arrive early is driven by the need to secure a nest site and territory (Winkler et al. 2016). The availability of cavities has been shown to limit the populations of cavitynesting birds (Holroyd 1975, Newton 1998). Thus migratory cavity-nesters that arrive first are most likely to secure a nest site. Knudsen et al. (2011) 
pointed out that any differences in the age and sex of cohorts affected by climate change are typically not reported or are unknown. In our study, the first bluebirds to arrive were males, which presumably arrived early to establish territories and claim a nest site (Johnson and Dawson 2019). The risk of arriving too early for an insectivore, however, is the increased chance of encountering adverse weather-an increase of which is another predicted result of anthropogenic climate change (Donat et al. 2016, Blunden and Arndt $2016,2017)$. Severe cold weather can reduce the availability of arthropods, impair the survival of adult birds, and depress their productivity over the long term (Holroyd and Beaubien 1997a, b, Wormworth and Şekercioglu 2011). Severe spring weather in central Alberta usually entails snowfall and often freezing temperatures, high wind, and wet, deep snow (Holroyd and Beaubien 1997a, b). Such conditions can reduce or eliminate opportunities for foraging on open ground and lead to high mortality (Newton 1998).

Changes, either too rapid or too slow, in timing of arrival can lead to reduced fitness through a temporal mismatch between consumer demands and resource availability (Mayor et al. 2017, Knudsen et al. 2011). Ultimately, a population's fitness may be compromised if migratory birds breed too early or too late relative to peak food resource availability, resulting in a trophic mismatch (Both et al. 2009, Thackeray et al. 2010). However, the Mountain Bluebird's trend to earlier arrival in March in central Alberta parallels plants' trend to earlier spring flowering (Beaubien and Freeland 2000). If the supply of arthropod prey is also more advanced in the warmer springs, any mismatch with bluebird nesting is reduced. We did not measure seasonal food availability or chick growth and survival during our study, so the extent to which changes in the Mountain Bluebird's breeding phenology is moderating the effects of climate change is unknown.

First arrival dates have been criticized since they do not necessarily reflect the arrival of the whole population of birds, and they are subject to variation in effort and to chance sightings (Knudsen et al. 2011, Pearce-Higgins and Green 2014). Lehikoinen et al. (2019) analyzed the continuous daily records of spring migration at 21 bird observatories and found that the earliest $5 \%$ of birds were arriving earlier even though the median and 95\% arrival did not advance as much. Nevertheless, they found an earlier arrival of 0.14 days per year for the populations of numerous species on two continents over a half century. Similarly, Pearce-Higgins and Green (2014) summarized first arrival dates in 79 studies and found a positive correlation between first and median arrival dates, indicating the utility of first arrival dates as a meaningful biological metric.

In our study, two biologists continued the efforts of two self-trained citizen scientists, then expanded efforts to include other observers of nearby trails of bluebird nest boxes. Thus the change in effort could have influenced the accuracy of any given year. However, the change in first arrival dates is so dramatic that we believe our observations reflect a true shift in the dates of the Mountain Bluebirds' arrival in central Alberta. Apparent first arrival dates can also be confounded if any apparent arrivals had actually wintered locally, but no winter records of the Mountain Bluebird in Alberta have been reported via www.eBird.org, so overwintering is not likely a consideration in this study.

We demonstrated that spring arrival of the Mountain Bluebird in central Alberta has advanced by 0.33 days per year over the past 58 years. Over the 
same period, spring temperatures have increased and snow depths have decreased, but these trends are not statistically significant because of wide year-to-year variation. Our findings suggest that climate change is influencing arrival dates of these short-distance migrants in central Alberta. An increase in snow-free areas as average snow depth decreases may be facilitating the trend. The development of strong El Niño events in the northern Pacific Ocean and wide annual variability in spring snow depth in western Canada are two of the many changes (Møller et al. 2010, Pearce-Higgins and Green 2014) that may affect the phenology of migratory birds in western Canada. Our study demonstrates the value of long-term data sets collected by citizen scientists, and also identifies the need for a better understanding of how spring temperatures and snow depth affect the availability and abundance of invertebrates. Since arrival dates have increased so significantly, yet temperature and snow depth are extremely variable, are Mountain Bluebirds responding to other, more meaningful cues? Further research could also investigate how changes in first arrival date affect the species' success in breeding.

\section{ACKNOWLEDGMENTS}

We thank the Red Deer and District Community Foundation for providing research funding to Ellis Bird Farm through the Conservation of Bluebirds, Swallows and other Native Cavity-nesting Birds Fund. We also appreciate the support of Ellis Bird Farm's Research Committee for assisting with this paper and acknowledge other reviewers: Harold E. Fisher, Kevin C. Fraser, Scott Gillihan, L. Scott Johnson, and Steve Matsuoka.

\section{LITERATURE CITED}

Beal, F. E. L. 1907. Birds of California in relation to the fruit industry, part 1. U.S. Dept. Agric. Biol. Survey Bull. 30; doi 10.5962/bhl.title.62785.

Beaubien, E. 2013. Spring flowering trends in Alberta, Canada: Response to climate change, urban heat island effects, and an evaluation of a citizen science network. Ph.D. thesis, Univ. Alberta, Edmonton, Canada.

Beaubien, E. G., and Freeland, H. J. 2000. Spring phenology trends in Alberta, Canada: Links to ocean temperature. Int. J. Biometeorol. 44:53-59; doi 10.1007/ s004840000050.

Bird, C. D., and Bird, R. D. 1967. The aspen parkland, in Alberta, a Natural History (W. G. Hardy, ed.), pp. 135-149. Hurtig, Edmonton, Alberta.

Blunden. J., and Arndt, D. S. (eds.). 2016. State of the climate in 2015. Bull. Am. Meteorol. Soc. 97:S1-S275; doi 10.1175/2016BAMSStateoftheClimate.1.

Blunden. J., and Arndt, D. S. (eds.). 2017. State of the climate in 2016. Bull. Am. Meteorol. Soc. 98:S1-S277; doi 10.1175/2017BAMSStateoftheClimate.1.

Both, C., Van Asch, M., Bijlsma, E. G., Van Den Burg, A. B., and Visser, M. E. 2009. Climate change and unequal phenological changes across four tropic levels: Constraints or adaptations? J. Anim. Ecol. 78:73-83; doi 10.1111/j.13652656.2008.01458.x.

Burnham, K. P., and Anderson, D. R. 2002. Model Selection and Multimodel Inference: A Practical Information-Theoretic Approach. Spring-Verlag, New York.

DeLeon, R. L., DeLeon, E. E., and Rising, G. R. 2011. Influence of climate change on avian migrants' first arrival dates. Condor 113:915-923; doi 10.1525/ cond.2011.100223.

Donat, M. G., Dunn, R. J. H., and Perkins-Kirkpatrick, S. E. 2016. Land surface temperature extremes. Bull. Am. Meteorol. Soc. 97:S192-S193. 
Gienapp, P., Leimu, R., and Merila, J. 2007. Responses to climate change in avian migration time-microevolution versus phenotypic plasticity. Climate Res. 35:25-35; doi 10.3354/cr00712.

Goodenough, A., Fairhurst, S. M., Morrison, J. B., Cade, M., Morgan, P. J., and Wood, M. J. 2015. Quantifying the robustness of first arrival dates as a measure of avian migratory phenology. Ibis 157:384-390; doi 10.3354/cr00712.

Gwinner, E. 1986. Circuannual Rhythms: Endogenous Annual Clocks in the Organization of Seasonal Processes. Springer-Verlag, Berlin.

Herlugson, C. J. 1982. Food of adult and nestling Western and Mountain Bluebirds. Murrelet 63:59-65; doi 10.2307/3533829.

Holroyd, G. L. 1975. Nest site availability as a factor limiting population size of swallows. Can. Field-Nat. 89:60-63.

Holroyd, G. L., and Beaubien, E. G. 1997a. Responses of prairie biodiversity to climate variability and change, in Preparing for Climate Variability and Change on the Canadian Prairies, Summary Report of a Workshop 14-15 February 1996 (R. Herrington, ed.), pp. 2.18-2.20. Environment Canada, Regina, Saskatchewan.

Holroyd, G. L., and Beaubien, E. G. 1997b. Some possible effects of atmospheric change on wildlife, in Ecosystem Effects of Atmospheric Change, Proceedings of a Meeting Held at Pointe Claire, Quebec, Canada, 5-6 March 1996, pp. 177-182. Natl. Water Res. Inst., Environment Canada, Burlington, Ontario.

Johnson, L. S., and Dawson, R. D. 2019. Mountain Bluebird (Sialia currucoides), version 2.0, in The Birds of North America (P. G. Rodewald, ed.). Cornell Lab. Ornithol., Ithaca, NY; doi 10.2173/bna.moublu.02.

Knudsen, E., Linden, A., Both, C., Jonzen, N., and Pulido, F. 2011. Challenging claims in the study of migratory birds and climate change. Biol. Rev. 86:928-946; doi 10.1111/j.1469-185X.2011.00179.x.

Lane, R. K., and Pearman, M. 2003. Comparison of spring return dates of Mountain Bluebirds (Sialia currucoides) and Tree Swallows (Tachycineta bicolor) with monthly air temperatures. Can. Field-Nat. 117:110-111.

Lehikoinen, A., Linden, A., Karlsson, M., Andersson, A., Crewe, T. L., Dunn, E. H., Gregory, G., Karlsson, L., Kristiansen, V., Mackenzie, S., Newman, S., Roer, J. E., Sharpe, C., Sokolov, L. V., Steinholtz, Å, Stervander, M., Tirri, I.-S., and Tjornlov, R. S. 2019. Phenology of the avian spring migratory passage in Europe and North America: Asymmetric advancement in time and increase in duration. Ecol. Indicators 101:985-991; doi 10.1016/j.ecolind.2019.01.083.

Lehikoinen, E., and Sparks, T. H. 2010. Changes in migration, in Effects of Climate Change on Birds (A. P. Møller, W. Fiedler, and P. Berthold, eds.), pp. 89-112. Oxford Univ. Press, Oxford, England.

Mayor, S. J., Guralnick, R. P., Tingley, M. W., Otequi, J., and Withey, J. C. 2017. Increasing phenological asynchrony between spring green-up and arrival of migratory birds. Sci. Rep. 7(1902); doi 10.1038/s41598-017-02045-z.

Mazerolle, M. J. 2019. AICcmodavg: Model selection and multimodel inference based on (Q)AIC(c). R package version 2.2-2; https://cran.r-project.org/ package $=$ AICcmodavg.

Møller, A. P., Fiedler, W., and Berthold, P. 2010. Effects of Climate Change on Birds. Oxford Univ. Press, Oxford, England.

Newton, I. 1998. Population Limitation in Birds. Elsevier Academic Press, Chicago.

Pearce-Higgins, J. W., and Green, R. E. 2014. Birds and Climate Change: Impact and Conservation Responses. Cambridge Univ. Press, Cambridge, England; doi 10.1017/CBO9781139047791.

Power, H. W., and Lombardo, M. P. 1996. Mountain Bluebird (Sialia currucoides), version 1.0, in The Birds of North America (A. F. Poole and F. B. Gill, eds.), no. 222. Acad. Nat. Sci., Philadelphia; doi 10.2173/bna.222. 
Pulido, F. 2007. Phenotypic changes in spring arrival: Evolution, phenotypic plasticity, effects of weather and conditions. Climate Res. 35:5023; doi 10.3354/cr00711.

R Core Team. 2019. R: A Language and Environment for Statistical Computing. R Foundation for Statistical Computing, Vienna, Austria; www.r-project.org.

Rowan, W. 1932. Experiments in bird migration. III. The effects of artificial light, castration and certain extracts on the autumn movements of the American Crow (Corvus brachyrhynchos). Proc. Natl. Acad. Sci. USA 18:639-654; doi 10.1073/pnas.18.11.639.

Schwartz, M. W., Ahas, R., and Aasa, A. 2006. Onset of spring starting earlier across the Northern Hemisphere. Global Change Biol. 12:343-351; doi 10.1111/j.13652486.2005.01097.x.

Senner, N. R., Stager, M., and Cheviron, Z. 2018. Spatial and temporal heterogeneity in climate change limits species' dispersal capabilities and adaptative potential. Ecography 41:1428-1440; doi 10.1111/ecog.03234.

Swanson, D. L., and Palmer, J. S. 2009. Spring migration phenology of birds in the northern prairie region is correlated with local climate change. J. Field Ornithol. 80:351-363; doi 10.1111/j.1557-9263.2009.00241.x.

Thackeray, S. J., Sparks, T. H., Frederiksen, M., Burthe, S., and Bacon, P. J. 2010. Trophic level asynchrony in rates of phenological change for marine freshwater and terrestrial environments. Global Change Biol. 16:3304-3313; doi 10.1111/j.1365-2486.2010.02165.x.

Ward, D. H., Helmericks, J., and Hupp, J. W. 2016. Multi-decadal trends in spring arrival of avian migrants to the central arctic coast of Alaska: Effects of environmental and ecological factors. J. Avian Biol. 47:197-207; doi 10.1111/jav.00774.

Winkler, D. W., Shamoun-Baranes, J., and Piersma, T. 2016. Avian migration and dispersal, in Handbook of Bird Biology (I. J. Lovette and J. W. Fitzpatrick, eds.), pp. 453-492. Wiley, Chichester, England.

Wormworth, J., and Şekercioglu, Ç. H. 2011. Winged Sentinels: Birds and Climate Change. Cambridge Univ. Press, Cambridge, England; doi 10.1017/ CBO9781139150026.

Accepted 19 December 2019 